\title{
PENGARUH PENGALAMAN MEREK DAN CITRA MEREK MENGGUNAKAN LIPSTIK PURBASARI DI KOTA PALU
}

\author{
DEBBI YANTI UTARI \\ ELIMAWATY ROMBE \\ PONIRIN \\ Program Studi S1 Manajemen Fakultas Ekonomi Universitas Tadulako \\ Email: debbiyanti248@gmail.com
}

\begin{abstract}
Cosmetics is part of the lifestyle of women, so many students and career women are increasingly aware of the importance of cosmetics to meet the lifestyle that is clean, healthy, and comfortable and interesting to look at. Lipstick products are cosmetic products that are being phenomenal and become a trend that is followed by women. This study aims to analyze the influence of brand experience and brand image on consumer loyalty, brand experience on consumer loyalty, and brand image of consumer loyalty. This study is a type of causal research. The population in this study were those who bought Purbasari lipstick in Palu city twice. Sampling technique in this study using purposive sampling, with the number of samples of 100 people. Data collection using questionnaires. The analytical method used multiple linear regression analysis. The results showed that there are simultaneous influence of brand experience and brand image on consumer loyalty using Purbasari lipstick, there is influence of product quality to loyalty of consumer of lipstick Purbasari and there influence of customer value to consumer loyalty using Purbasari lipstick in Palu city.
\end{abstract}

Keywords: brand experience, brand image, customer loyalty.

\begin{abstract}
Abstrak
Kosmetik merupakan bagian dari gaya hidup wanita, sehingga banyak mahasiswa maupun wanita karir semakin menyadari akan pentingnya kosmetik untuk memenuhi gaya hidup yang bersih, sehat, serta nyaman dan menarik untuk dipandang. Produk lipstik merupakan produk kosmetik yang sedang fenomenal dan menjadi sebuah tren yang diikuti oleh para wanita. Penelitian ini bertujuan untuk menganalisis pengaruh pengalaman merek dan citra merek terhadap loyalitas konsumen, pengalaman merek terhadap loyalitas konsumen, dan citra merek terhadap loyalitas konsumen. Penelitian ini merupakan jenis penelitian kausal. Populasi dalam penelitian adalah yang membeli lipstik Purbasari di kota Palu sebanyak 2 kali. Teknik penarikan sampel dalam penelitian ini menggunakan purposive sampling, dengan jumlah sampel sebanyak 100 orang. Pengambilan data menggunakan kuesioner. Metode analisis yang digunakan analisis regresi linear berganda. Hasil penelitian menunjukkan bahwa terdapat pengaruh serempak pengalaman merek dan citra merek terhadap loyalitas konsumen menggunakan lipstik Purbasari, terdapat pengaruh kualitas produk terhadap loyalitas konsumen lipstik Purbasari dan terdapat pengaruh nilai pelanggan terhadap loyalitas konsumen menggunkan lipstik Purbasari di kota Palu.
\end{abstract}

Kata kunci: pengalaman merek, citra merek, loyalitas pelanggan.

\section{PENDAhUluAN}

Gaya hidup dan kosmetik tidak bisa lepas dari kaum wanita. Hampir semua wanita bergantung kepada produk kosmetik, terutama bagi wanita yang aktif berkerja, mereka dituntut untuk selalu berpenampilan menarik. Fenomena tersebut embuat kaum wanita harus menentukan pilihan produk yang sesuai dengan diri mereka. Seiring perkembangan produk kosmetik, konsumen wanita menjadi lebih aktif dalam mengakses informasi. Mereka menjadi semakin teliti dalam menentukan produk yang akan dibeli. Terlebih keberadaan internet juga semakin memudahkan penggunanya untuk mendapatkan berbagai informasi yang dibutuhkan. Pengetahuan konsumen akan produk semakin berkembang karena konsumen memiliki kendali atas akses informasi yang semakin mudah serta arus informasi yang semakin cepat dan bebas. 
Produk lipstik merupakan produk kosmetik yang sedang fenomenal dan menjadi sebuah tren yang diikuti oleh para wanita di Kota Palu. Jenis lipstik telah mendominasi tren rias wajah wanita tahun 2017. Seriring dengan kemunculan tren tersebut, produk lipstik Purbasari tidak hanya menjadi buah bibir di kalangan pengguna kosmetik, namun produk tersebut juga sangat diminati hingga sempat mengalami kelangkaan produk.

Semakin banyak pilihan produk, masyarakat menjadi semakin selektif sehingga ia berubah menjadi lebih aktif untuk mencari informasi produk sebelum memutuskan melakukan pembelian. Hal tersebut juga memicu berkembangnya aktivitas masyarakat yang membuat review produk untuk membantu memberikan informasi mengenai pengalaman setelah menggunakan produk. Fenomena tersebut memiliki keterkaitan dengan merek, karena review produk yang ditulis oleh pengguna, sebagian besar menyebutkan nama merek. Hal tersebut akan menimbulkan pengaruh terhadap persepsi atau penerimaan khalayak/publik terhadap merek yang diperbincangkan.

Untuk dapat mendefinisikan lebih jauh mengenai pengalaman merek. Brakus et al., (2009) memulai penelitian dengan melihat sudut pandang konsumen dengan menguji pengalaman konsumen itu sendiri dan bagaimana pengalaman itu menghasilkan pendapat sikap, dan aspek lainnya dari perilaku konsumen. Brand experience dimulai pada saat konsumen mencari produk, membeli, menerima pelayanan dan mengkonsumsi produk. Brand experience dapat dirasakan secara langsung maupun secara tidak langsung saat konsumen melihat iklan atau juga saat pemasar mengkomunikasikan produk melalui website.

Penelitian ini berfokus pada citra merek karena adanya perubahan sikap konsumen terhadap merek Purbasari yang terlihat sangat jelas. Berawal dari kemunculan review produk, banyaknya khalayak yang mengakses, hingga konsumen memutuskan pembelian. Penelitian ini dilakukan untuk mengetahui seberapa besar pengaruh pada pengalaman merek dan citra merek terhadap loyalitas konsumen, serta untuk mengetahui seberapa besar loyalitas konsumen kosmetik di kota Palu atas produk lipstik Purbasari.

\section{KAJIAN LITERATURE DAN PERKEMBANGAN HIPOTESIS}

Menurut Kotler \& Keller (2009) merek merupakan istilah, tanda, lambang, atau desain, atau kombinasinya, yang dimaksudkan untuk mengidentifikasikan barang atau jasa dari salah satu penjual atau kelompok penjual dan mendiferensikan mereka dari para pesaing maka merek adalah produk atau jasa yang di mensinya mendiferensikan merek dengan beberapa cara, definisi merek merupakan hal yang sangat penting, baik bagi konsumen maupun produsen, dari sisi konsumen, merek mempermudah pembelian. Bila tidak ada merek, konsumen harus mengevaluasi semua produk yang tidak memiliki merek setiap kali mereka akan melakukan pembelian. Mereka juga membantu menyakinkan konsumen bahwa mereka akan mendapatkan kualitas yang konsisten ketika mereka membeli produk tersebut, dari sisi produsen, merek dapat dipromosikan. Merek dapat dengan mudah diketahui ketika diperhatikan atau ditempatkan dalam suatu display.

Pengalaman merek didefinisikan sebagai sensasi, perasaan, kognisi dan tanggapan konsumen yang ditimbulkan oleh merek, terkait rangsangan yang ditimbulkan oleh desain merek, identitas merek, komunikasi pemasaran, orang dan lingkungan merek tersebut dipasarkan. Untuk dapat mendefinisikan lebih jauh mengenai pengalaman merek. Brakus et al.(2009) memulai penelitian dengan melihat sudut pandang konsumen dengan menguji pengalaman konsumen itu sendiri dan bagaimana pengalaman itu menghasilkan pendapat sikap, dan aspek lainnya dari perilaku konsumen. Pengalaman merek dimulai pada saat konsumen mencari produk,membeli,menerima pelayanan dan mengkonsumsi produk. Pengalaman merek dapat dirasakan secara langsung maupun secara tidak langsung saat konsumen melihat iklan atau juga saat pemasar mengkomunikasikan produk melalui website. (Brakus et al., 2009). 
Pengalaman merek dapat dikonseptualisasikan sebagai sensasi, perasaan, kognisi, dan respon perilaku ditimbulkan oleh rangsangan merek terkait yang merupakan bagian dari desain merek dan identitas, kemasan, dan komunikasi (Zarantonello, Schmit, \& Brakus, 2009). Sementara itu pengalaman merek terjadi ketika konsumen berinteraksi dengan produk sebagai contoh, ketika konsumen melakukan pencarian akan suatu produk dan mengevaluasinya. Pengalaman merek terjadi secara langsung ketika konsumen melakukan kontak langsung dengan dan dapat terjadi secara tidak langsung melalui iklan atau presentase secara virtual.

Sulistian \& Ogi (2011) mendefinisikan citra merek sebagai seperangkat keyakinan, ide, dan kesan yang dimiliki oleh seseorang terhadap suatu merek, karena itu sikap dan tindakan konsumen terhadap suatu merek sangat ditentukan oleh citra merek tersebut. Citra yang dibentuk harus jelas dan memiliki keunggulan bila dibandingkan dengan pesaingnya, saat perbedaan dan keunggulan merek dihadapkan dengan merek lain.

Loyalitas (loyalty) sebagai komitmen yang dipegang secara mendalam untuk membeli atau mendukung kembali produk atau jasa yang disukai dimasa depan meski pengaruh situasi dan usaha pemasaran berpotensi menyebabkan pelanggan beralih. Loyalitas pelanggan sangat penting artinya bagi perusahaan yang menjaga kelangsungan maupun kelangsungan kegiatan usahanya. Membangun dan mempertahankan loyalitas pelanggan sebagai bagian dari suatu program hubungan jangka panjang sebuah perusahaan, terbukti dapat memberikan manfaat bagi para pelanggan dan organisasi. Bagi organisasi terdapat empat manfaat utama yang berkaitan dengan loyalitas pelanggan (Kotler \& Keller 2009).

Penelitian yang dilakukan Imama (2017) berjudul "Pengaruh Citra Merek Dan Kepercayaan Merek Terhadap Loyalitas Pelanggan (Studi Pada Konsumen Lipstik Wardah di Matahari Departement Store Plaza Surabaya)" dalam kehidupan modern seperti saat ini, tidak jarang kita temui konsumen yang memutuskan untuk memilih dan mengkonsumsi produk tertentu dalam rangka aktualisasi diri sekaligus sebagai sarana masuk kedalam komunitas yang diharapkannya. Misalkan dalam konsumsi kosmetik. Kosmetika suci dan aman merupakan salah konsep yang diusung oleh salah satu merek kosmetik Indonesia.

\title{
Kerangka Pemikiran
}

Kerangka pemikiran menjelaskan mengenai variabel independen yaitu citra merek $\left(\mathrm{X}_{1}\right)$ dan pengalaman merek $\left(\mathrm{X}_{2}\right)$ yang memiliki pengaruh secara serempak dan parsial terhadap variabel dependen yaitu loyalitas (Y). Maka dapat dijelaskan, semakin baik citra merek dan pengalaman merek terhadap suatu objek maka semakin besar pengaruhnya terhadap loyalitas konsumen. Hal tersebut dapat dilihat pada gambar berikut ini:

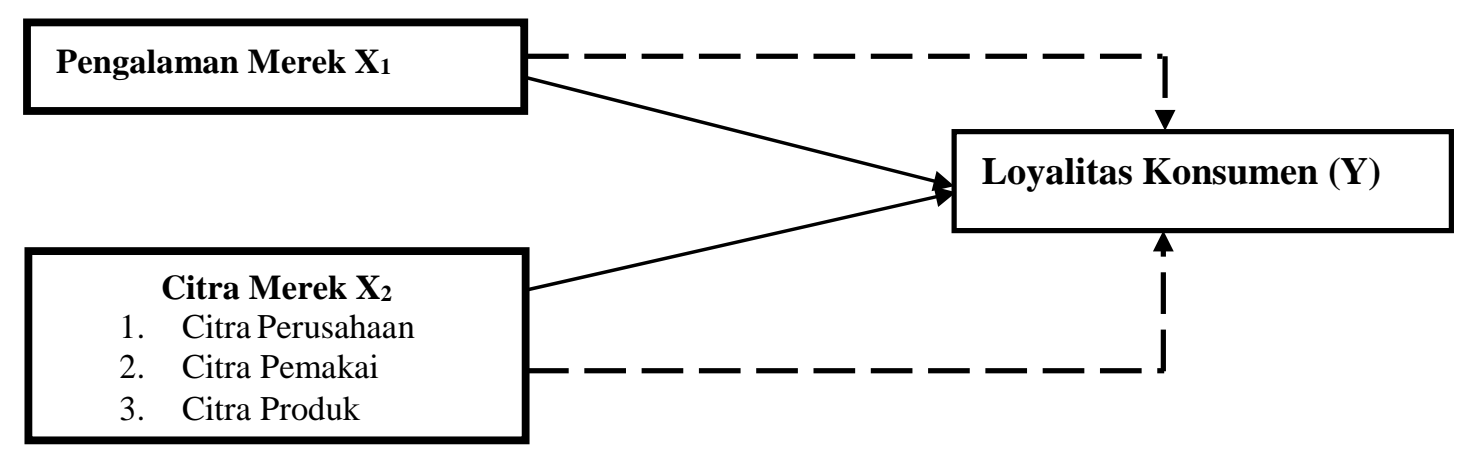

\author{
Gambar 1 \\ Kerangka Pemikiran
}




\section{Hipotesis}

Berdasarkan latar belakang, rumusan masalah, serta kerangka pemikiran di atas maka peneliti merumuskan hipotesis untuk acuan dalam penelitian ini adalah

1. Variabel pengalaman merek secara simultan berpengaruh terhadap loyalitas konsumen.

2. Variabel pengalaman merek berpengaruh terhadap loyalitas konsumen

3. Variabel citra merek perpengauh terhadap loyalitas konsumen

\section{METODE PENELITIAN}

Penelitian ini merupakan jenis penelitian kausal dimana ditujukan untuk menganalisis hubungan sebab akibat antar variabel yaitu variabel-variabel pengalaman merek, citra merek sebagai variabel bebas dan loyalitas konsumen sebagai variabel terikat. Populasi penelitian yang akan diteliti adalah konsumen pengguna produk Lipstik Purbasari. Teknik pengambilan sampel yang digunakan dalam penelitian ini adalah teknik Purposive Sampling. Pada pengambilan sampel ditentukan beberapa kriteria yaitu yang menggunakan Lipstik Purbasari. Kriteria sampel yang diambil dalam penelitian ini adalah pelanggan yang telah berkunjung sebanyak 3 kali dan didapatkan sebanyak 100 responden. Adapun kriteria responden yang di jadikan sampel dalam penelitian ini adalah berusia 17 tahun atau lebih, pernah membeli dan menggunakan produk lipstik Purbasari sebanyak 2 kali dalam 3 bulan terakhir dan berdomisili di kota Palu.

Menurut Sugiyono (2010:117) populasi adalah wilayah generalisasi yang terdiri atas obyek/subyek yang mempunyai kualitas dan karakteristik tertentu yang ditetapkan oleh peneliti untuk dipelajari dan kemudian ditarik kesimpulannya. Jadi populasi bukan hanya orang, tetapi juga obyek dan benda-benda alam yang lain, dalam penelitian ini populasi yang akan diteliti adalah konsumen pengguna produk Lipstik Purbasari.

Teknik pengambilan sampel yang digunakan dalam penelitian ini adalah teknik Purposive Sampling. Menurut (Sugiyono, 2012:117) Teknik Purposive Sampling adalah teknik penentuan sampel berdasarkan kriteria atau pertimbangan tertentu. Pada pengambilan sampel ditentukan beberapa kriteria yaitu yang menggunakan Lipstik Purbasari. Agar sampel yang diambil representatif, dalam proses penelitian masing-masing responden didampingi peneliti, sehingga dalam hal ini peneliti menerangkan hal-hal yang berkaitan dengan kualitas produk dan nilai pelanggan terhadap loyalitas pelanggan. Kriteria sampel yang diambil dalam penelitian ini adalah pelanggan yang telah berkunjung sebanyak 3 kali.

Mmenentukan jumlah sampel dalam penelitian ini, maka penulis merujuk pada pendapat (Sugiyono, 2012:103) Bila dalam penelitian akan melakukan analisis multivariate (kolerasi atau regresi berganda misalnya), maka jumlah anggota sampel minimal 10 kali dari jumlah variabel yang diteliti. Misalnya variabel penelitiannya ada 3 (independen + dependen), maka jumlah anggota sampel $=34 \times 3=102$. Variabel dalam penelitian ini adalah 3 yang terdiri dari variabel indepen dan dependen. Berdasarkan pertimbangan tersebut maka jumlah sampel sebesar 34 x 3 variabel yaitu 102 responden dengan demikian sampel dari penelitian ini sebanyak 100 responden.

Klasifikasi variabel pada penelitian ini dibagi atas dua yaitu variabel independen (variabel bebas) dan variabel dependen (variabel terikat/dipengaruhi). Berdasarkan kategori tersebut, maka variabel independen $(X)$ dalam penelitian ini adalah pengalaman merek $\left(X_{1}\right)$ dan citra merek $\left(X_{2}\right)$ sertavariabel dependen (Y) yaitu loyalitas konsumen. Untuk memudahkan analisis maka masing-masing hipotesis yang diajukan diuraikan berdasarkan klasifikasi variabel sebagai berikut:

Variabel bebas merupakan variabel yang mempengaruhi faktor-faktor yang diukur, dimanipulasi atau dipilih oleh peneliti untuk menentukan hubungan antara fenomena yang diobservasi atau yang menjadi sebab perubahannya atau timbulnya vaiabel terkait (dependent) (Sugiyono, 2009), dalam penelitian ini variabel bebasnya adalah pengalaman merek $\left(\mathrm{X}_{1}\right)$, citra merek $\left(\mathrm{X}_{2}\right)$. 
Variabel terkait merupakan variabel yang dipengaruhi atau yang menjadi akibat, karena adanya variabel bebas. Variabel terkait ini di lambangkan dengan huruf Y. Variabel terkait dalam penelitian ini adalah Loyalitas konsumen. Peneliti menggunakan tiga metode pengumpulan data, yaitu observasi, wawancara, dan kuesioner yang telah dilakukan uji validitas dan realibilitas. Skala Likert digunakan untuk mengukur sikap, pendapat dan presepsi seseorang atau sekelompok tentang kejadian atau gejala sosial. Penelitian ini dilakukan uji normalitas dengan menggunakan One Sample KolmogrovSmirnovtest dengan menggunakan taraf signifikansi 0,05 , data dinyatakan berdistribusi normal jika signifikansi lebih besar dari 5\% atau 0,05. Analisis yang digunakan dalam penelitian ini adalah dengan pendekatan statistik deskriptif melalui penggunaan alat analisis statistik Regresi Linear Berganda, dalam hal ini, menggunakan bantuan komputer program SPSS 16 For Windows.

\section{HASIL DAN PEMBAHASAN}

\section{HASIL PENELITIAN}

Berikut hasil mengenai pengaruh variabel bebas baik secara serempak maupun parsial yang diolah SPSS 16.0 dengan analisis regresi linier berganda seperti pada tabel 1 berikut ini:

\section{Tabel 1}

\section{Hasil Uji Analisis Regresi Linear Berganda}

\begin{tabular}{|c|c|c|c|c|c|}
\hline \multicolumn{6}{|c|}{ Dependen Variabel $Y=$ Loyalitas konsumen } \\
\hline \multirow[t]{2}{*}{ Variabel Independen } & \multicolumn{2}{|c|}{ Unstandardized Coefficients } & \multirow{2}{*}{$\begin{array}{c}\text { Standardized } \\
\text { Coefficients }\end{array}$} & \multirow[t]{2}{*}{$\mathbf{T}$} & \multirow[t]{2}{*}{ Sig. } \\
\hline & $\mathbf{B}$ & Std. Error & & & \\
\hline (Constant) & 0,308 & 0,342 & & 0,900 & 0,370 \\
\hline X1 (Pengalaman Merek) & 0,405 & 0,108 & 0,363 & 3,752 & 0,000 \\
\hline X2 (Citra Merek) & 0,424 & 0,105 & 0,392 & 4,052 & 0,000 \\
\hline
\end{tabular}

Adjusted R Square $\quad=0,458 \alpha \quad=0,05$ tingkat loyalitas $95 \%$

Sumber: Data diolah Tahun 2018

\section{PEMBAHASAN}

Pengalaman merek $\left(\mathrm{X}_{1}\right)$

Pengalaman merek merupakan sensasi, perasaan, kognisi dan tanggapan konsumen yang ditimbulkan oleh merek, terkait rangsangan yang ditimbulkan oleh desain merek, identitas merek, komunikasi pemasaran, orang dan lingkungan merek tersebut dipasarkan. Pengalaman merek dimulai pada saat konsumen mencari produk, membeli, menerima pelayanan dan mengkonsumsi produk. Pengalaman merek dapat dirasakan secara langsung maupun secara tidak langsung saat konsumen melihat iklan atau juga saat pemasar mengkomunikasikan produk melalui website, dari penelitian yang dilakukan pada pengguna lipstik Purbasari yang telah membeli sebanyak 2 kali selama 3 bulan terakhir, Berdasarkan hasil penelitian ini menunjukan bahwa variabel pengalaman merek berpengaruh positif dan signifikan terhadap kepuasan pelanggan. Berdasarkan indikator pengalaman merek yang diukur pada penelitian ini tampaknya konsumen sebelum membeli produk lipstik Purbasari konsumen terlebih dahulu melihat tampilan kemasan maupun aroma produk tersebut.

\section{Citra Merek $\left(\mathrm{X}_{2}\right)$}

Citra merek merupakan seperangkat keyakinan, ide, dan kesan yang dimiliki oleh seseorang terhadap suatu merek. Karena itu sikap dan tindakan konsumen terhadap lipstik Purbasari sangat 
ditentukan oleh citra merek tersebut. Konsumen yang memiliki citra yang positif terhadap lipstik Purbasari, akan lebih memungkinkan untuk melakukan pembelian. Melalui citra merek, konsumen dapat mengenali lipstik Purbasari, mengevaluasi kualitas, mengurangi risiko pembelian, dan memperoleh pengalaman tertentu serta mendapatkan loyalitas tertentu dari suatu produk. Semakin baik persepsi konsumen terhadap lipstik Purbasari maka dapat dikatakan bahwa citra merek mengenai merek tersebut telah berhasil dibangun dan seterusnya dapat memberikan tingkat kepuasan yang lebih tinggi dari penggunanya.

\section{KESIMPULAN DAN SARAN}

\section{Kesimpulan}

Berdasarkan hasil penelitian yang telah dijabarkan, maka diperoleh kesimpulan mengenai pengaruh pengalaman merek dan citra merek terhadap loyalitas konsumen menggunakan lipstik Purbasari di Kota Palu.

1. Pengalaman merek dan citra merek secara simultan berpengaruh signifikan terhadap loyalitas konsumen menggunakan lipstik Purbasari di Kota Palu.

2. Pengalaman merek secara parsial berpengaruh signifikan terhadap loyalitas konsumen menggunakan lipstik Purbasari di Kota Palu.

3. Citra merek secara parsial berpengaruh signifikan terhadap loyalitas konsumen menggunakan lipstik Purbasari di Kota Palu.

\section{Saran}

Berdasarkan kesimpulan yang telah diuraikan sebelumnya, maka saran-saran yang tepat menyangkut kegunaan penelitian ini dapat diuraikan sebagai berikut:

1. Tetap mempertahankan produk lipstik Purbasari dan menyediakan merek lipstik Purbasari sehingga dapat meningkatkan penjualannya karna apabila merek lipstik Purbasari produknya stabil mengikuti pasar maka akan lebih berpengaruh terhadap loyalitas konsumen dan dapat meningkatkan penjualannya .

2. Sebaikanya merek lipstik Purbasari lebih memahami karakteristik dari konsumen misalnya merek lipstik Purbasari menyediakan beragam produk agar perusahaan akan lebih mudah menarik konsumen untuk membeli lipstik Purbasari.

3. Sebaiknya perusahaan menjadikan produk ini sebagai pilihan utama di antara semua jenis produk yang ada agar konsumen lebih menarik terhadap produk lipstik Purbasari.

\section{REFERENSI}

Brakus, Schmitt, \& Zarantonello. (2009). Brand experience, 73(2).

Imama, K. (2017). Pengaruh Citra Merek Dan Kepercayaan Merek Terhadap Loyalitas Pelanggan (Studi Pada Konsumen Lipstik Wardah di Matahari Departement Store Plaza Surabaya). Jurnal Pendidikan Tata Niaga (JPTN), 1(2).

Kotler, \& Keller. (2009). Manajemen Pemasaran (13th ed.). Jakarta: Erlangga.

Sugiyono. (2010). Metode Penelitian Bisnis (Pendekatan Kuantitatif, kualitatif dan R end D).

Bandung: Alfabeta.

Sugiyono. (2009). Metode Penelitian Bisnis (Pendekatan Kuantitatif, kualitatif dan R end D).

Bandung: Alfabeta.

Sugiyono. (2012). Metode Penelitian Manajemen. Bandung: Alfabeta.

Sulistian, \& ogi. (2011). Pengaruh Brand Image Terhadap Loyalitas Pelanggan Rokok Gudang Garam Filte. 